\title{
Possibility of using 'chickpea aquafaba' as egg replacer in traditional cake formulation
}

\author{
Geleneksel kek formülasyonunda yumurta yerine nohut suyu kullanımı
}

Mine ASLAN ${ }^{1}$ iD Nilgün ERTAŞ $^{1 *}$ iD

${ }^{1}$ Necmettin Erbakan University, Engineering and Architecture Faculty, Food Engineering, Köyceğiz Campus, Konya, 42050, Turkey

To cite this article:

Aslan, M. \& Ertaş, N. (2020). Possibility of using 'chickpea aquafaba' as egg replacer in traditional cake formulation. Harran Tarım ve Gıda Bilimleri Dergisi, 24(1): 1-8.

DOI: 10.29050/harranziraat.569397

Address for Correspondence: Nilgün ERTAŞ

e-mail:

dr.nilgunertas@gmail.com

Received Date:

23.05.2019

Accepted Date:

20.01.2020

(C) Copyright 2018 by Harran University Faculty of Agriculture. Available on-line at www.dergipark.gov.tr/harranziraat

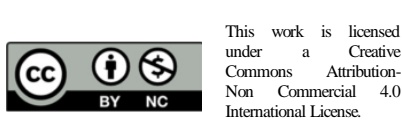

\section{ABSTRACT}

The objective of this study was to determinate the possibility of substituting egg with chickpea aquafaba at different levels (0-25-50-75-100\%) in cake formulation and the quality characteristics of cake made with aquafaba. Physical (color analysis, volume index, symmetry index, and uniformity index), chemical (moisture, $\mathrm{pH}$ ash, protein) and sensorial properties of the cake samples were evaluated. $25 \%$ aquafaba- $75 \%$ whole egg and $50 \%$ aquafaba-50\% whole egg mixtures resulted in higher foaming capacity values than whole egg and the other replacement levels of aquafaba. Whole egg and aquafaba gave similar foaming stability values. While the use of up to $25 \%$ aquafaba gave similar volume index values with control cake sample. Using more than $50 \%$ aquafaba in cake formulation concluded with an increase in firmness values. $50 \%$ aquafaba added cake sample showed desired uniformity index values close to $0.00 \mathrm{~mm}$. Results showed that increasing the aquafaba in the cake samples from 0 to $100 \%$ decreased crumb redness. The results of sensory evaluation indicated that samples containing $25 \%$ aquafaba were more preferred by panelists.

Key Words: Aquafaba, Cake, Chickpea water, Egg, Egg replacer

Öz

Bu çalışmada, kek formulasyonunda yumurta yerine \%0-25-50-75-100 oranlarında nohut suyu ikame edilebilme potansiyeli araştırılmış ve nohut suyu ile üretilen kek örneklerinin kalite karakteristikleri belirlenmiştir. Kek örneklerinin fiziksel (renk analizi, hacim indeksi, simetri indeksi, tek düzelik), kimyasal (rutubet, $\mathrm{pH}$, kül, protein) ve duyusal özellikleri incelenmiştir. \%25 nohut suyu-\%75 tüm yumurta ve \%50 nohut suyu -\%50 tüm yumurta karışımları, yumurta ve nohut suyunun diger ikame oranlarına göre daha çok köpük kapasitesi değeri göstermiştir. \%25 nohut suyu kullanımı ile kontrol örneğe benzer hacim indeksi değeri elde edilirken \%50 den fazla nohut suyu kullanım oranı hacim indeksinde düşmeye ve kek sıkılığında bir artışa sebep olmuştur. \%50 nohut suyu kullanılan kek örneğinde $0.00 \mathrm{~mm}$ değerine yakın istenen tek düzelik indeks değeri elde edilmiştir. Kek içi kırmızılık değerinin \%0 dan \%100 e nohut suyu kullanımı ile azaldığı belirlenmiştir. Duyusal analiz sonuçlarına gore panelistler tarafından \%25 nohut suyu içeren kek örneği daha çok tercih edilmiştir.

Anahtar Kelimeler: Aquafaba, Kek, Nohut suyu, Yumurta, Yumurta ikamesi

\section{Introduction}

Cake is a ready-to-use food product produced by using $8-9 \%$ protein wheat flour, sugar, fat, eggs, milk and some additives (Noğay, 2014; Köklü and Özer, 2008). Eggs are the most important component in cake formulation in terms of both cake texture and nutrition. Egg white proteins are responsible for foam formation, emulsification, stabilization, elasticity while egg yolk used as binding, coloring, flavoring and emulsification agents (Lin et al. 2017a; 
Kiosseoglou et al., 2014). Despite these positive effects, the consumption of eggs is limited for some individuals because of personal dietary preferences such as vegan-vegetarian, egg allergy, religious beliefs and health problems such as health diseases (Arozarena et al., 2001).

Aquafaba is the perfect solution for these diseases. Various studies have been carried out to develop alternative egg substitutes which can be used partially or completely instead of eggs in cake formulations as lentil protein (Jarpa-Parra et al., 2017), pea proteins (Lin et al., 2017b), soybean protein isolates (Lin et al., 2017a), soy milk (Rahmati and Tehrani, 2014a; Hedayati and Tehrani, 2018), whey proteins (Paraskevopoulou et al., 2015), hydrocolloids and emulsifiers (Shao et al., 2015; Rahmati and Tehrani, 2014b). Aquafaba is also known as 'sticky liquid da among the people. The reason for this is that when the legumes are cooked, the starch inside them is absorbed by water and eventually breaks down into amylose and amylopectin and also protein and sugar are absorbed by cooking water together. Moreover, recently, the viscous liquid 'aquafaba' produced from cooked legumes is considered an egg substitution in many foods due to nutritional and functional properties such as foaming, emulsifying, binding and thickening (Mustafa et al., 2018).

The objective of the present study was to determine physical, chemical and sensorial quality properties of cake produced using different levels of 'chickpea aquafaba' instead of eggs.

\section{Materials and Methods}

\section{Materials}

Chickpea seeds, wheat flour, sugar, shortening, whole egg, salt, baking powder, vanillin purchased from a local market in Konya, Turkey. The other ingredients used in the cake were xanthan gum (Vatan Gıda, Istanbul, Turkey) and diacetyl tartaric acid esters of monoglycerides and diglycerides (DATEM; Rikevita Sdn Bhd, Johor, Malaysia).

\section{Aquafaba Production}

Aquafaba was obtained by cooking chickpea with water (1:5 chickpea/water ratio) for $30 \mathrm{~min}$ in boiling water at $98^{\circ} \mathrm{C}$ then waited for $12 \mathrm{hr}$ and drained with modifying the procedure of Baik and Han (2012).

\section{Methods}

Control cake recipe from Rahmati and Tehrani (2014b) was used, with slight modifications. Cake prepared with wheat flour (100 g), shortening (50 g), sugar (75 g), egg (60 g), milk powder (8 g), salt $(0.2 \mathrm{~g})$, baking powder $(3 \mathrm{~g})$, vanillin $(1 \mathrm{~g})$, DATEM $(0.5 \mathrm{~g})$ and xanthan gum (0.5 g). Other cake samples were produced using 25-50-75-100\% ratio aquafaba instead of eggs. Control cake sample was prepared using $60 \mathrm{~g}$ egg without incorporation of aquafaba. The water amount in the recipe determined between 35 and $45 \mathrm{ml}$ based on pre-trials. To obtain the cakes, sugar and egg were blended to a cream in a Hobart mixer (Hobart N50, Canada Inc., North York, Ontario, Canada) at a high speed for 5 min firstly. Later, other ingredients were added into the mixer and mixed for $1 \mathrm{~min}$. For each cake, $130 \mathrm{~g}$ of cake batter was poured into a cake pan $(7.5 \times 6.6 \times 12 \mathrm{~cm})$ and baked at $160{ }^{\circ} \mathrm{C}$ for $50 \mathrm{~min}$ in a preheated oven (Bosch HBT 112, Athens, Greece). The cake samples were kept at room temperature to cool for $60 \mathrm{~min}$ before analyses.

Foaming capacity and foam stability of whole egg, aquafaba and mixtures thereof in different proportions were determined according to modification of Liu et al., 2010 and Martinez et al., 2016. $15 \mathrm{ml}$ egg replacer in a $50 \mathrm{ml}$ graduated cylinder were foamed using an digital ultra-turrax at $10000 \mathrm{rpm}$ for $2 \mathrm{~min}$, and then were measured foam volume at $0 \mathrm{~min}\left(\mathrm{~V}_{\mathrm{FO}}\right)$ and after $30 \mathrm{~min}$ $\left(\mathrm{V}_{\mathrm{F} 30}\right)$. Foaming capacity and foam stability were calculated using Eqs.1 and 2, respectively,

$\%$ Foaming Capacity $=\frac{V F 0}{\text { Vsamples }} \times 100$

$\%$ Foam Stability $=\frac{V F 30}{V F 0} \times 100$ 
The raw materials and the cake samples were analyzed for their moisture (AACC 44-01), ash (AACC 08-01), and protein (AACC 46-12) according to AACC (1990). The color of cake samples was determined measuring $L^{*}$ (lightness/darkness), $a^{*}$ (redness/greenness) and $b^{*}$ (yellowness/ blueness) parameters with a colorimeter (Model CR 400 Chromo meter, Minolta, Japan). Chroma and hue angle of cake samples were calculated from $a^{*}$ and $b^{*}$. Cake batter $\mathrm{pH}$ was determined using a digital $\mathrm{pH}$ meter (WTW pH315i/set) by mixing $10 \mathrm{~g}$ dough with $90 \mathrm{ml}$ distilled water for 1 min. Cake batter density was calculated by dividing the weight of a standard measure of the batter by the weight of an equal volume of water (Jyotsna et al., 2007). Volume, symmetry and uniformity index were calculated according to the AACC method 10-91 (AACC, 1990). Firmness was determined by a TA-XT2 Texture Analyzer (Texture Tech. Corp., England, and U.K.) at room temperature using an aluminium P36/R cylinder probe. The optimal test conditions in this study were: strain was $25 \%$, and the pre-test, test and post-test speeds were 1.0, 1.0 and $10.0 \mathrm{~mm} / \mathrm{s}$, respectively.

The baking loss (\%) was determined by dividing the difference between the weight of batter before and after baking and cooling to the weight of the batter before baking (Diaz-Ramirez et al., 2016). Sensory analysis of cake samples was conducted by 20 panelists (between 25 and 45 age) in the Food Engineering Department of Necmettin Erbakan University, Konya, Turkey. The panelists were selected based on their interest, non-smoker and non-food allergic. The sensory analysis was performed under daylight room conditions, and samples were randomly presented. Sensory properties (color, smell, taste, pore structure, appearance and overall acceptability) of cake samples were rated on a 17 scale by panelists. Statistical analysis was performed by using JMP software.

\section{Results and Discussion}

Foaming properties of the egg which is one of the main ingredients of the cake production, contributes to improving structure/texture of batter and final products (Singh et al., 2016; Singh and Ramaswamy, 2013; Van der Plancken et al., 2005). Furthermore, the stability of the air bubbles formed in the protein network structure of the egg albumin during the foaming may be enhanced with the effect of the occurring film around the air bubbles as a result of protein denaturation which is the process of partial globular proteins (Liand and Kristinsson, 2007; Lomakina and Miková, 2006). The foam properties of the egg replacer used in the cake formulation are shown in Table 1. Foaming capacity values ranged from $126.67 \%$ to $253.33 \%$ and foam stability values ranged from $91.89 \%$ to $94.74 \%$. Although aquafaba has a lower foaming capacity than egg, the use of aquafaba up to $50 \%$ level instead of egg was provided a statistically significant increase in foaming capacity. On the other hand, the foam stability of the aquafaba showed similar characteristics compared to the egg. There was no statistically significant difference between foaming stability values ( $p>0.05)$ in whole egg and aquafaba replacement levels.

Table 1. Foaing properties of egg and replacers ${ }^{1}$

Çizelge 1. Yumurta ve ikamelerinin köpürme özellikleri ${ }^{1}$

\begin{tabular}{lcc}
\hline $\begin{array}{l}\text { Samples } \\
\text { Örnekler }\end{array}$ & Foaming capacity (\%) & $\begin{array}{l}\text { Foam stability (\%) } \\
\text { Köpük kapasitesi (\%) }\end{array}$ \\
\hline 100\%Whole Egg stabilitesi (\%) \\
25\%Aquafaba-75\%Whole Egg & $200.00 \pm 14.8^{\mathrm{b}}$ & $93.33 \pm 2.00^{\mathrm{a}}$ \\
50\%Aquafaba-50\%Whole Egg & $253.33 \pm 10.9^{\mathrm{a}}$ & $94.21 \pm 2.19^{\mathrm{a}}$ \\
75\%Aquafaba-25\%Whole Egg & $246.67 \pm 8.9^{\mathrm{a}}$ & $91.89 \pm 2.04^{\mathrm{a}}$ \\
100\%Aquafaba & $186.67 \pm 12.7^{\mathrm{c}}$ & $92.14 \pm 1.40^{\mathrm{a}}$ \\
\hline
\end{tabular}

${ }^{1}$ Means followed by the same letter within column are non-significantly different $(P<0.05)$. 


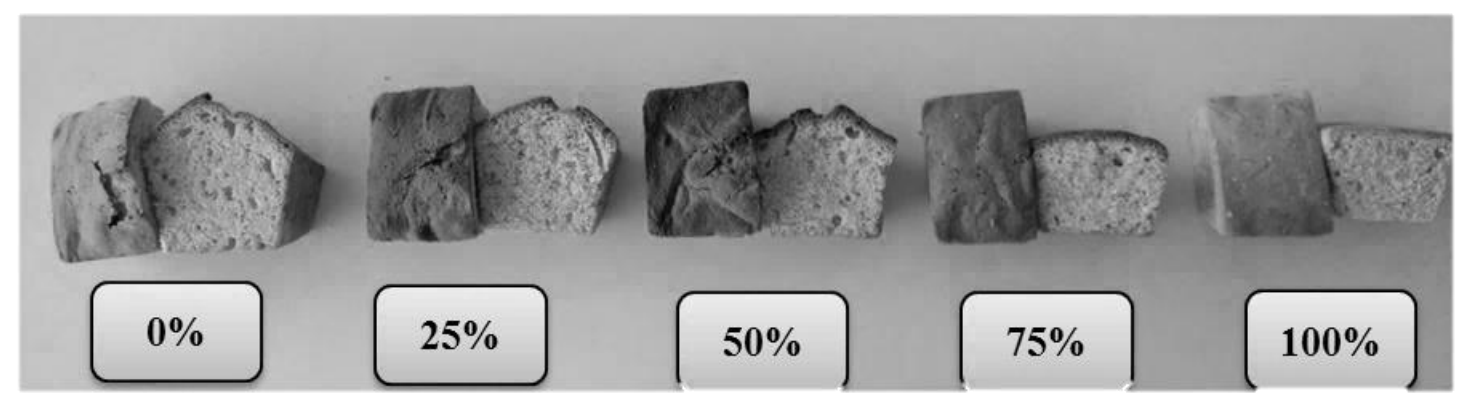

Figure 1. Cake samples

Şekil 1. Kek örnekleri

The prepared chickpea aquafaba was incorporated into traditional cake at 25, 50, 75 and $100 \%$, as an egg substitute. Figure 1 presents the obtained cakes.

Chemical composition of cake samples are given in Table 2. As a result of cooking of legumes, water soluble carbohydrates such as sugar, sucrose, raffinose, stachyose and verbascose are dispersed into the cooking water (Stantiall et al., 2018; Ghribi et al., 2015). Therefore, dry matter of cake samples increased with the use of more than $50 \%$ chickpea aquafaba addition rate, compared to the control sample. The protein content of cake samples varied from 6.39 to 9.98\% and decreased $(P<0.05)$ with $100 \%$ chickpea aquafaba addition ratio but this decrease is just about $3 \%$. Ash contents of cake samples varied from 1.20 to $1.30 \%$ and ash contents of cake samples decreased with aquafaba addition. But $25 \%$ aquafaba added cake sample gave statistically similar ash content with control sample. This can be explained as follows, although high protein was found in chickpea seeds, less water soluble protein or ash pass into the cooking water seems to be the reason (Stantiall et al., 2018; Cherian et al., 2012). Batter density values are given in Table 2 . The highest density was obtained from control cake batter incorporated with egg. Similar result was found by Jyotsna et al., (2007) a study used whey protein concentrate instead of egg.

Optimum cake volume, cake pore structure and texture are obtained by providing the appropriate $\mathrm{pH}$ value (Pyler, 1988). As shown in Table 2, the $\mathrm{pH}$ value of the cake sample decreased from 7.24 to 6.70 , aquafaba addition resulted lower $\mathrm{pH}$ values compared to control sample.

Table 2. Chemical properties and batter gravity of cake samples.

Çizelge 2. Kek örneklerinin kimyasal özellikleri ve hamur yoğunluğu ${ }^{1}$

\begin{tabular}{|c|c|c|c|c|c|}
\hline $\begin{array}{l}\text { Aquafaba (\%) } \\
\text { Nohut suyu (\%) }\end{array}$ & $\begin{array}{l}\text { Dry matter (\%) } \\
\text { Kuru madde (\%) }\end{array}$ & $\begin{array}{l}\text { Protein (\%) } \\
\text { Protein (\%) }\end{array}$ & $\begin{array}{l}\text { Ash (\%) } \\
\text { Kül (\%) }\end{array}$ & $\begin{array}{l}\text { Batter } \mathrm{pH} \\
\text { Hamur } \mathrm{pH}\end{array}$ & $\begin{array}{l}\text { Batter gravity }\left(\mathrm{g} \mathrm{cm}^{-3}\right) \\
\text { Hamur yoğunluğu }\left(\mathrm{g} \mathrm{cm}^{-3}\right)\end{array}$ \\
\hline 0 & $79.63 \pm 0.43^{c}$ & $9.98 \pm 0.18^{\mathrm{a}}$ & $1.30 \pm 0.01^{\mathrm{a}}$ & $7.24 \pm 0.17^{\mathrm{a}}$ & $1.10 \pm 0.04^{\mathrm{a}}$ \\
\hline 25 & $78.87 \pm 0.37^{c}$ & $7.53 \pm 0.15^{b}$ & $1.29 \pm 0.03^{\mathrm{a}}$ & $7.09 \pm 0.12^{\mathrm{ab}}$ & $1.08 \pm 0.01^{\mathrm{ab}}$ \\
\hline 50 & $82.62 \pm 0.31^{a}$ & $7.26 \pm 0.19^{b c}$ & $1.25 \pm 0.03^{\mathrm{ab}}$ & $7.10 \pm 0.11^{\mathrm{ab}}$ & $1.03 \pm 0.02^{b c}$ \\
\hline 75 & $82.98 \pm 0.39^{a}$ & $7.00 \pm 0.16^{c}$ & $1.22 \pm 0.01^{b}$ & $7.06 \pm 0.11^{\mathrm{ab}}$ & $1.04 \pm 0.03^{b c}$ \\
\hline 100 & $80.75 \pm 0.28^{b}$ & $6.39 \pm 0.15^{d}$ & $1.20 \pm 0.01^{b}$ & $6.70 \pm 0.14^{b}$ & $1.01 \pm 0.02^{c}$ \\
\hline
\end{tabular}

${ }^{1}$ Means followed by the same letter within column are non-significantly different $(P<0.05)$.

The increase in the cake batter $\mathrm{pH}$ is caused an increase in cake volume and large cake pore structure, while a decrease in cake batter $\mathrm{pH}$ is lead to firmer cakes, smaller pore structure, and lower cake volume (Pyler, 1988). As was expected, the volume index values of the cake samples decreased from 169 to $128 \mathrm{~mm}$ as a result of the $\mathrm{pH}$ change resulting from egg substitution (Table 3). According to
Paraskevopoulou et al. (2015), the decrease in cake volume is due to the better gas retention capacity of the control batter with higher ratio egg and a more controlled structure development during baking. Cake volume depends on not only air incorporated in the batter but also to retain available air during cooking (Paraskevopoulou et al., 2015; Sahi and Alava, 2003). A similar result was reported by Tan et al. (2015) that the egg- 
free cake samples had a lower volume. Cake symmetry index values were ranged between 3 and $16 \mathrm{~mm}$. In the cake industry, the symmetry index is used to determine the profiles of the outer lines of the cakes and the increase in the symmetry index indicates that the cake is formed from the center to the top and booming, and that the cake has a flat top surface (Mercan, 1998; Bath et al., 1992). Uniformity index values ranged from -0.45 to 0.25 , also the highest value was determined with cake samples used $25 \%$ chickpea aquafaba. The uniformity index in the cake industry is used to determine the symmetry of the cake (Masoodi et al., 2002; Mercan, 1998). It is desirable that the results obtained are close to zero (Mercan, 1998; Bath et al., 1992). 50\% aquafaba added cake sample gave creditable $(0.00 \mathrm{~mm})$ uniformity index values.

Baking loss and firmness values of cake samples are demonstrated in Table 3. Results showed that as chickpea aquafaba ratio increased, the baking loss was changed from 12.72 to 13.74 but this change was not statistically significant $(P<0.05)$. The changes in baking loss values can be explained by the fact that the egg-containing cake formulations have a higher water binding capacity than the formulations prepared with egg substitution (Ratnayake et al., 2012).

Table 3. Physical properties of cake samples. ${ }^{1}$

Çizelge 3. Kek örneklerinin fizksel özellikleri ${ }^{1}$

\begin{tabular}{|c|c|c|c|c|c|}
\hline $\begin{array}{l}\text { Aquafaba (\%) } \\
\text { Nohut suyu (\%) }\end{array}$ & $\begin{array}{l}\text { Volume index } \\
\text { (mm) } \\
\text { Hacim indeksi } \\
(\mathrm{mm})\end{array}$ & $\begin{array}{l}\text { Symmetry index } \\
(\mathrm{mm}) \\
\text { Simetri indeksi }(\mathrm{mm})\end{array}$ & $\begin{array}{l}\text { Uniformity index } \\
\text { (mm) } \\
\text { Tek düzelik } \\
\text { Indeksi }(\mathrm{mm})\end{array}$ & $\begin{array}{l}\text { Baking loss (\%) } \\
\text { Pişme kaybı } \\
\text { (\%) }\end{array}$ & $\begin{array}{l}\text { Firmness (g) } \\
\text { Sıkılık }(g)\end{array}$ \\
\hline 0 & $169 \pm 2.12^{\mathrm{a}}$ & $15.5 \pm 0.14^{\mathrm{ab}}$ & $-0.45 \pm 0.07^{c}$ & $12.72 \pm 1.78^{a}$ & $508.26 \pm 29.5^{c}$ \\
\hline 25 & $165.5 \pm 2.12^{a}$ & $8.5 \pm 0.28^{\mathrm{cd}}$ & $0.25 \pm 0.14^{a}$ & $13.21 \pm 1.50^{\mathrm{a}}$ & $545.60 \pm 34.44^{b c}$ \\
\hline 50 & $158 \pm 1.41^{b}$ & $16.0 \pm 0.21^{\mathrm{a}}$ & $0.00 \pm 0.07^{\mathrm{ab}}$ & $13.48 \pm 1.48^{\mathrm{a}}$ & $569.05 \pm 35.86^{b c}$ \\
\hline 75 & $130.5 \pm 2.12^{c}$ & $3.0 \pm 0.14^{d}$ & $-0.40 \pm 0.14^{c}$ & $13.19 \pm 1.60^{\mathrm{a}}$ & $610.13 \pm 25.27^{\mathrm{ab}}$ \\
\hline 100 & $128 \pm 2.12^{c}$ & $10.0 \pm 0.28^{b c}$ & $-0.20 \pm 0.07^{b c}$ & $13.74 \pm 1.88^{\mathrm{a}}$ & $656.35 \pm 39.54^{\mathrm{a}}$ \\
\hline
\end{tabular}

${ }^{1}$ Means followed by the same letter within column are non-significantly different $(P<0.05)$.

Firmness values of cake samples produced with $100 \%$ chickpea aquafaba were significantly higher compare to the control cake samples $(P<0.05)$. An increase in firmness values was determined in cake samples contained isolated pea proteins instead of eggs by Lin et al. (2017b). crumb and crust color of cake samples are presented in Table 4 and Table 5, respectively. Crumb lightness $\left(L^{*}\right)$ of the cake samples varied between 69.71 and 73.00 with different chickpea aquafaba addition level. More than $75 \%$ addition level of aquafaba showed statistically similar lightness values with control cake sample. In addition, crumb $a^{*}$ values slightly increased at higher replacement levels of egg, and $b^{*}$ values significantly decreased. Because the internal temperature of cake is not high enough for the formation of the Maillard and caramelization reactions, cake crumb color values are mostly dependent on the cake ingredients (Levent and Bilgiçli, 2013; Gómez et al., 2010). Egg, especially yolk is the main factor of changes the color of cake. Crumb chroma values of cake samples significantly $(P<0.05)$ decreased and also hue angle values decreased slightly.

Table 4. Crumb color properties of cake samples. ${ }^{1}$ Çizelge 4. Kek örneklerinin kabuki renk özellikleri ${ }^{1}$

\begin{tabular}{lllccc}
\hline $\begin{array}{l}\text { Aquafaba (\%) } \\
\text { Nohut suyu (\%) }\end{array}$ & \multicolumn{1}{c}{$L^{*}$} & $a^{*}$ & $b^{*}$ & Chroma & Hue angle \\
\hline 0 & $73.00 \pm 1.02^{\mathrm{a}}$ & $-0.42 \pm 0.03^{\mathrm{c}}$ & $24.91 \pm 0.19^{\mathrm{a}}$ & $24.92 \pm 0.19^{\mathrm{a}}$ & $90.97 \pm 0.03^{\mathrm{a}}$ \\
25 & $69.71 \pm 0.85^{\mathrm{b}}$ & $-0.41 \pm 0.04^{\mathrm{c}}$ & $23.91 \pm 0.22^{\mathrm{b}}$ & $23.91 \pm 0.22^{\mathrm{b}}$ & $90.98 \pm 0.04^{\mathrm{a}}$ \\
50 & $71.93 \pm 1.12^{\mathrm{ab}}$ & $-0.38 \pm 0.03^{\mathrm{c}}$ & $22.59 \pm 0.26^{\mathrm{c}}$ & $22.60 \pm 0.26^{\mathrm{c}}$ & $90.97 \pm 0.08^{\mathrm{a}}$ \\
75 & $72.57 \pm 0.99^{\mathrm{a}}$ & $-0.26 \pm 0.03^{\mathrm{b}}$ & $20.56 \pm 0.22^{\mathrm{d}}$ & $20.56 \pm 0.22^{\mathrm{d}}$ & $90.73 \pm 0.24^{\mathrm{ab}}$ \\
100 & $72.99 \pm 1.08^{\mathrm{a}}$ & $-0.13 \pm 0.01^{\mathrm{a}}$ & $19.41 \pm 0.20^{\mathrm{e}}$ & $19.41 \pm 0.20^{\mathrm{e}}$ & $90.37 \pm 0.02^{\mathrm{b}}$ \\
\hline
\end{tabular}

${ }^{1}$ Means followed by the same letter within column are non-significantly different $(P<0.05)$. 
Compare to control samples, using $100 \%$ chickpea aquafaba increased the crust lightness of cake samples significantly $(P<0.05)$, whereas crust redness values of cake samples significantly decreased $(P<0.05)$. Results of the crust color represented that yellowness value of control cake higher than the other cake samples with chickpea aquafaba. Both chroma and hue angle values of cake crust color significantly decreased until $75 \%$ chickpea aquafaba addition compare to control cake samples. Crust color of cake is affected
Maillard reactions, interaction reducing sugarsamino acids and caramelization reactions of sugars (Hedayati and Tehrani, 2018). According to Rahmati and Tehrani (2014a), the reason for this increase may be due to the higher protein content of the egg than egg substitutions.

Sensory properties of cake samples are shown in Figure 2. Generally, control sample (without chickpea aquafaba) is given the highest score in terms of all

Table 5. Crust color properties of cake samples. ${ }^{1}$

Çizelge 5. Kek örneklerinin iç renk özellikleri ${ }^{1}$

\begin{tabular}{llllll}
\hline Aquafaba (\%) & $L^{*}$ & $a^{*}$ & $b^{*}$ & Chroma & Hue angle \\
Nohut suyu (\%) & Parlaklık & Kirmızlık & Sarılık & & \\
\hline 0 & $49.21 \pm 1.48^{\mathrm{b}}$ & $12.07 \pm 0.24^{\mathrm{a}}$ & $28.30 \pm 0.34^{\mathrm{a}}$ & $30.77 \pm 0.41^{\mathrm{a}}$ & $66.90 \pm 0.16^{\mathrm{a}}$ \\
25 & $50.42 \pm 1.52^{\mathrm{ab}}$ & $11.63 \pm 0.25^{\mathrm{ab}}$ & $25.30 \pm 0.26^{\mathrm{b}}$ & $27.84 \pm 0.34^{\mathrm{b}}$ & $65.31 \pm 0.25^{\mathrm{b}}$ \\
50 & $50.59 \pm 1.54^{\mathrm{ab}}$ & $11.01 \pm 0.25^{\mathrm{bc}}$ & $21.68 \pm 0.25^{\mathrm{c}}$ & $24.32 \pm 0.34^{\mathrm{c}}$ & $63.08 \pm 0.26^{\mathrm{c}}$ \\
75 & $52.40 \pm 1.45^{\mathrm{ab}}$ & $11.14 \pm 0.22^{\mathrm{bc}}$ & $18.39 \pm 0.33^{\mathrm{d}}$ & $21.50 \pm 0.39^{\mathrm{d}}$ & $58.81 \pm 0.05^{\mathrm{d}}$ \\
100 & $53.51 \pm 1.54^{\mathrm{a}}$ & $10.86 \pm 0.27^{\mathrm{c}}$ & $25.31 \pm 0.28^{\mathrm{b}}$ & $27.55 \pm 0.36^{\mathrm{b}}$ & $66.78 \pm 0.30^{\mathrm{a}}$ \\
\hline
\end{tabular}

${ }^{1}$ Means followed by the same letter within column are non-significantly different $(P<0.05)$.

sensory characteristics. Compared to the control samples, the use of aquafaba up to $75 \%$ level in cake samples showed statistically similar color scores and the lowest color scores was given for $100 \%$ aquafaba added cake samples by the panelists. The most affected property was the smell among the sensorial properties. Smell scores decreased with aquafaba addition. According to the taste scores of the cake samples, the use of egg substitution until 50\% level was shown similar effect with control cake, but with 75 and $100 \%$ substitution of aquafaba instead of egg, the samples received lower scores from panelists. Pore structure scores decreased with aquafaba addition because of the shrinkage of the pores and a tighter structure in the cake. In terms of appearance, the use of aquafaba up to $25 \%$ level in cake samples showed statistically similar color scores compared to control cake. According to overall acceptability properties, similar features of control cakes with up to $50 \%$ usage were observed and no negative effects were observed.

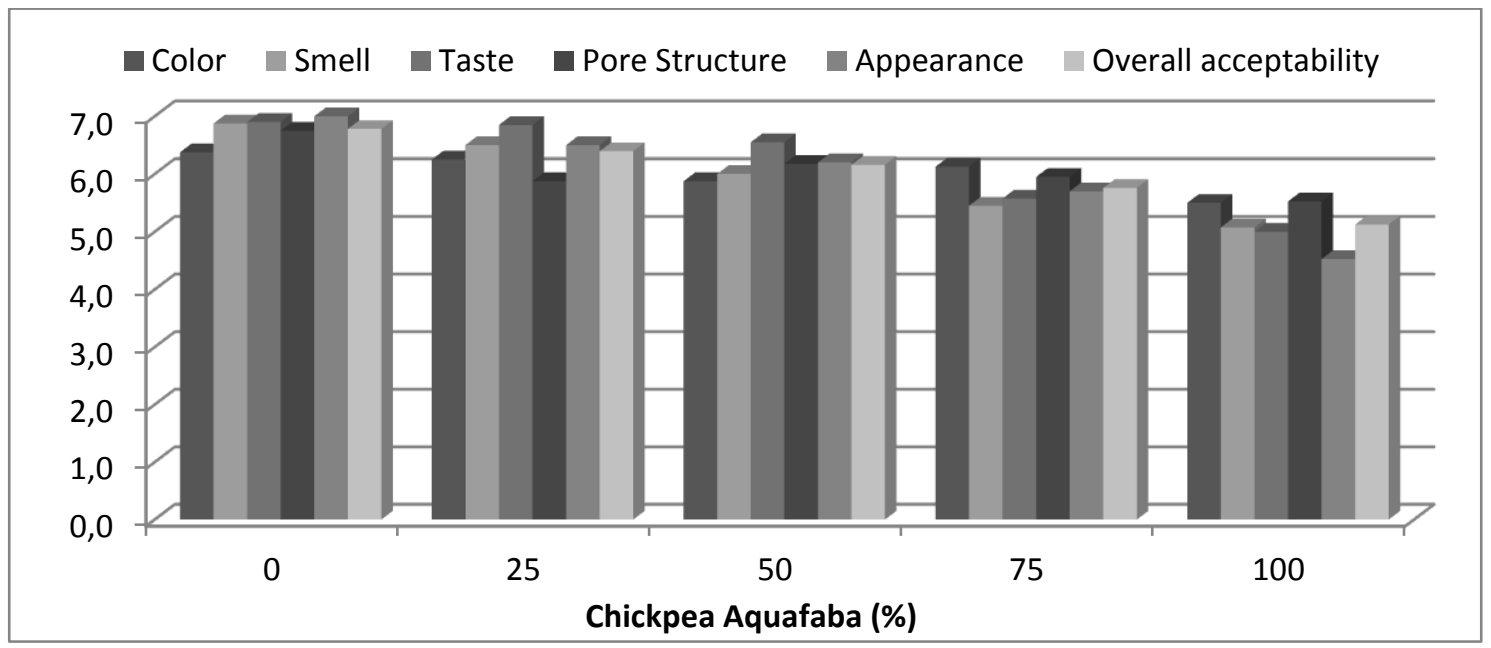

Figure 2. Sensory properties of cake sample Şekil 2. Kek örneklerinin duyusal özellikleri 


\section{Conclusions}

When all the results are evaluated, the use of chickpea aquafaba as an egg substitute was concluded with a decrease in the protein and ash content of cake samples, and in terms of physical properties considerably not caused a negative effect up to $50 \%$ ratio and showed similar foaming stability values. Addition of egg substitution resulted in an increase of crumb redness and a decrease of crust yellowness values. Compared to the control samples, the use of aquafaba up to $75 \%$ level in cake samples showed statistically similar color scores. As a result, chickpea aquafaba can be used $50 \%$ as an alternative source instead of eggs for vegans with regard to both cost and effects on nutrition.

\section{References}

American Association of Cereal Chemists (AACC), Approved methods, AACC, (1990). Washington, DC, USA,

Arozarena, I., Bertholo, H., Empis, J., Bunger, A., and Sousa, I. (2001). Study of the total replacement of egg by white lupine protein, emulsifiers and xanthan gum in yellow cakes. European Food Research and Technology, $213 \quad$ (4-5), 312-316. https://doi.org/10.1007/s002170100391

Baik, B. K., and Han, I. H. (2012). Cooking, roasting, and fermentation of chickpeas, lentils, peas, and soybeans for fortification of leavened bread. Cereal Chemistry, 89(6), 269-275. https://doi.org/10.1094/CCHEM-04-12-0047-R.

Bath, D.E., Shelke, K., and Hoseney, R.C. (1992). Fat replacers in high ratio cake layer cakes. Cereal Foods World. 37(7), 495-500.

Cherian, B. M., Leão, A. L., Caldeira, M. D. S., Chiarelli, D., de Souza, S. F., Narine, S., and de Morais Chaves, M. R. (2012). Use of saponins as an effective surface modifier in cellulose nanocomposites. Molecular Crystals and Liquid Crystals, 556(1), 233-245. https://doi.org/10.1080/15421406.2012.635969.

Díaz-Ramírez, M., Calderón-Domínguez, G., García-Garibay, M., Jiménez-Guzmán, J., Villanueva-Carvajal, A., de la Paz Salgado-Cruz, M., and Del Moral-Ramírez, E. (2016). Effect of whey protein isolate addition on physical, structural and sensory properties of sponge cake. Food Hydrocolloids, 61, 633-639. https://doi.org/10.1016/j.foodhyd.2016.06.020.

Ghribi, A. M., Sila, A., Gafsi, I. M., Blecker, C., Danthine, S., Attia, H., and Besbes, S. (2015). Structural, functional, and ACE inhibitory properties of watersoluble polysaccharides from chickpea flours. International Journal of Biologcal Macromolecules, 75, 276-282. https://doi.org/10.1016/j.ijbiomac.2015.01.037.

Gómez, M., Moraleja, A., Oliete, B., Ruiz, E., and Caballero,
P.A. (2010). Effect of fibre size on the quality of fibreenriched layer cakes. LWT-Food Science and Technology, 43(1), 33-38. https://doi.org/10.1016/j.Iwt.2009.06.026

Hedayati, S., and Mazaheri Tehrani, M. (2018). Effect of total replacement of egg by soymilk and lecithin on physical properties of batter and cake. Food Science \& Nutrition, 6(4), 1154-1161. https://doi.org/10.1002/fsn3.656.

Jarpa-Parra, M., Wong, L., Wismer, W., Temelli, F., Han, J., Huang, W., and Chen, L. (2017). Quality characteristics of angel food cake and muffin using lentil protein as egg/milk replacer. International Journal of Food Science \& Technology, 52(7), 16041613. https://doi.org/10.1111/ijfs.13433.

Jyotsna, R., Sai Manohar, R., Indrani, D., and Venkateswara Rao, G. (2007). Effect of whey protein concentrate on the rheological and baking properties of eggless cake. International Journal of Food Properties, 10(3), 599-606. https://doi.org/10.1080/10942910601048986.

Kiosseoglou, V., and Paraskevopoulou, A. (2014). Eggs. In. Zhou, Y. H. Hui, I. D. Leyn, M. A. Pagani, C. M. Rosell, J. D. Selman, et al. (eds.), Bakery Products Science and Technology, Chichester: John Wiley \& Sons, Ltd., 243-258.

https://doi.org/10.1002/9781118792001.ch13.

Köklü, G., and Özer, M.S. (2008). A Study On Effects Of Some Emulsifiers On Cake Quality In Sponge Type Cake Production. Çukurova University Insitute of Natural and Applied Science, 19(2), 78-87.

Levent, H., and Bilgiçli, N. (2013). Quality evaluation of wheat germ cake prepared with different emulsifiers. Journal of Food Quality, 36(5), 334-341. https://doi.org/10.1111/jfq.12042.

Liang, Y., and Kristinsson, H.G. (2007). Structural and foaming properties of egg albumen subjected to different $\mathrm{pH}$-treatment in the presence of calcium ions. Food Research International, 40(6), 668-678. https://doi.org/10.1016/j.foodres.2006.11.015.

Lin, M., Tay, S. H., Yang, H., Yang, B., and Li, H. (2017b). Development of eggless cakes suitable for lactovegetarians using isolated pea proteins. Food Hydrocolloids, 69, 440-449. https://doi.org/10.1016/j.foodhyd.2017.03.014.

Lin, M., Tay, S. H., Yang, H., Yang, B., and Li, H. (2017a). Replacement of eggs with soybean protein isolates and polysaccharides to prepare yellow cakes suitable for vegetarians. Food Chemistry, 229, 663-673. https://doi.org/10.1016/j.foodchem.2017.02.132.

Liu, S., Elmer, C., Low, N.H., and Nickerson, M.T. (2010). Effect of $\mathrm{pH}$ on the functional behaviour of pea protein isolate-gum arabic complexes. Food Research International, 43(2), 489-495. https://doi.org/10.1016/j.foodres.2009.07.022.

Lomakina, K., and Miková, K. (2006). A study of the factors affecting the foaming properties of egg white - a review. Czech Journal of Food Sciences, 24(3), 110118.

Martinez, M., Stone, A. K., Yovchev, A. G., Peter, R., Vandenberg, A., and Nickerson, M. T. (2016). Effect of genotype and environment on the surface characteristics and functionality of air-classified faba 
bean protein concentrates. European Food Research and Technology, 242(11), 1903-1911. https://doi.org/10.1007/s00217-016-2690-4.

Masoodi, F.A., Sharma, B., and Chauan, G.S. (2002). Use of apple pomace as a source of diet dry fiber in cakes. Plant Foods for Human Nutrition, 57(2), 121128. https://doi.org/10.1023/A:1015264032164.

Mercan, N. (1998). Investigations on the effects of some emulsifiers on cake quality. M.Sc. Thesis, Istanbul University, Food Engineering Department, Istanbul, Turkey.

Mustafa, R., He, Y., Shim, Y. Y., and Reaney, M. J. (2018). Aquafaba, wastewater from chickpea canning, functions as an egg replacer in sponge cake. International Journal of Food Scirnce \& Technology, 53(10), 2247-2255. https://doi.org/10.1111/ijfs.13813.

Noğay, O. (2014). Effect of pomegranate seed powders obtained by different methods of quality characteristics of muffin cake. M.Sc. Thesis, Pamukkale University, Food Engineering Department, Denizli, Turkey.

Paraskevopoulou, A., Donsouzi, S., Nikiforidis, C. V., and Kiosseoglou, V. (2015). Quality characteristics of eggreduced pound cakes following WPI and emulsifier incorporation. Food Research International, 69, 7279. https://doi.org/10.1016/j.foodres.2014.12.018.

Pyler, E. J. (1988). Baking Science and Technology. Sosland Publishing Company, USA, 1345.

Rahmati, N. F., and Mazaheri Tehrani, M. (2014a). Replacement of egg in cake: Effect of soy milk on quality and sensory characteristics. Journal of Food Processing and Preservation, 39(6), 574-582. https://doi.org/10.1111/jfpp.12263.

Rahmati, N. F., and Tehrani, M. M. (2014b). Influence of different emulsifiers on characteristics of eggless cake containing soy milk: Modeling of physical and sensory properties by mixture experimental design. Journal of Food Science and Technology, 51(9), 16971710. https://doi.org/10.1007/s13197-013-1253-y.

Ratnayake, W. S., Geera, B., and Rybak, D. A. (2012). Effects of egg and egg replacers on yellow cake product quality. Journal of Food Processing and Preservation, 36(1), 21-29. https://doi.org/10.1111/j.17454549.2011.00547.x.

Sahi, S. S., and Alava, J. M. (2003). Functionality of emulsifiers in sponge cake production. Journal of the Science of Food Agriculture, 83(14), 1419-1429. https://doi.org/10.1002/jsfa.1557.

Shao, Y. Y., Lin, K. H., and Chen, Y. H. (2015). Batter and product quality of eggless cakes made of different types of flours and gums. Journal of Food Processing and Preservation, 39(6), 2959-2968. https://doi.org/10.1111/jfpp.12547.

Singh, A., Geveke, D. J., Jones, D. R., and Tilman, E. D. (2019). Can acceptable quality angel food cakes be made using pasteurized shell eggs? The effects of mixing factors on functional properties of angel food cakes. Food Science \& Nutrition, 7(3), 987-996. https://doi.org/10.1002/fsn3.911.

Singh, A., and Ramaswamy, H. (2013). Effect of high pressure processing on color and textural properties of eggs. Journal of Food Research, 2(4), 11. http://dx.doi.org/10.5539/jfr.v2n4p11.

Stantiall, S. E., Dale, K. J., Calizo, F. S., and Serventi, L. (2018). Application of pulses cooking water as functional ingredients: the foaming and gelling abilities. European Food Research and Technology, 244(1), 97-104. https://doi.org/10.1007/s00217017-2943-x.

Tan, M. C., Chin, N. L., Yusof, Y. A., Taip, F. S., and Abdullah, J. (2015). Improvement of eggless cake structure using ultrasonically treated whey protein. Food and Bioprocess Technology, 8(3), 605-614. https://doi.org/10.1007/s11947-014-1428-1.

Van der Plancken, I., Van Loey, A., and Hendrickx, M. E. (2005). Combined effect of high pressure and temperature on selected properties of egg white proteins. Innovative Food Science \& Emerging Technologies, 6(1), 11-20. https://doi.org/10.1016/j.ifset.2004.10.002 